\title{
POLITICAL DISAGREEMENT AND MINIMAL EPISTOCRACY
}

\author{
Adam F. Gibbons
}

1 EPARTING FROM democratic ideals is heavily controversial among most contemporary western philosophers. Democracy, in its various forms, is widely seen as the all-things-considered best political arrangement. Still, recent work in political philosophy has challenged this orthodoxy. Central to these challenges lie worries about high levels of voter ignorance among modern democratic populations. Such ignorance, one might think, leads democracies to occasionally produce bad outcomes. If that is right, perhaps allocating comparatively more political power to voters who know more politically relevant facts will lead to better outcomes. Call political arrangements that make the possession of a certain amount of political knowledge a legal requirement for holding political power epistocratic. ${ }^{1}$

In a recent paper, Julian Reiss articulates an important challenge to epistocracy. ${ }^{2}$ At the core of any defense of epistocracy is the conviction that we can reliably identify a subset of voters who possess more politically relevant knowledge than others. But if we cannot identify such a subset of voters, the case for epistocracy falls at the first hurdle. We cannot allocate comparatively more political power to voters who know more politically relevant facts if we cannot even identify such voters.

Why think that we are unable to identify the appropriate subset of voters? Oversimplifying for the moment, it is natural to think that such voters should possess knowledge of various politically relevant social-scientific facts. Perhaps they should possess knowledge of basic economics, sociology, political science, and more. However, the social sciences are filled with controversy, and this controversy makes it exceedingly difficult to know which facts ought to be known by voters. Indeed, it makes it difficult to know the relevant facts at all. Reiss claims that since there are no uncontroversial social-scientific facts, we

1 There are several forms of epistocracy. See Brennan, Against Democracy, 204-30, for discussion.

2 Reiss, "Expertise, Agreement, and the Nature of Social Scientific Facts." 
cannot definitively say of some voters that they possess more politically relevant knowledge than others. The prevalence of disagreement about most issues in the social sciences precludes the possibility of identifying an uncontroversial body of knowledge against which to measure the putative competence of potential voters. Call this the Argument from Political Disagreement. ${ }^{3}$

In this paper, I respond to the Argument from Political Disagreement. After outlining the argument at length, I begin by arguing that there is a distinction between social-scientific knowledge and politically relevant knowledge. Not all politically relevant knowledge is social scientific, and there is much uncontroversial politically relevant knowledge. More specifically, there are basic political facts, and knowledge of these facts requires no acquaintance with the social sciences. I then establish the significance of knowledge of these basic political facts. While these basic political facts can seem more like unimportant political trivia than vital political information, knowledge of such facts is often central to voter decision-making. This body of knowledge paves the way for a minimal epistocracy wherein those who possess more of the relevant knowledge are allocated comparatively more political power.

\section{THE ARGUMENT FROM POLITICAL DISAGREEMENT}

Epistocrats think that we should allocate comparatively more political power to voters who possess more politically relevant knowledge. What constitutes politically relevant knowledge? Defenses of epistocracy emphasize the importance of social-scientific knowledge. Among other things, voters should have some knowledge of basic economics, sociology, political science, and the like. ${ }^{4}$ For example, one might think that the near consensus view among economists indicates that restrictive immigration policies harm the global economy, or that price controls are generally to be avoided. ${ }^{5}$ When voters are ignorant of such facts, they might vote for political candidates endorsing objectively harmful policies. ${ }^{6}$ Addition-

3 A challenge to epistocracy not considered in this paper questions the purported relationship between possessing more knowledge of politically relevant facts and competent political decision-making (Estlund, Democratic Authority, 206-22; Gaus, "Is the Public Competent?"). Even if we can reliably identify more knowledgeable voters, there is no guarantee that they will competently make political decisions. As outlined here, the Argument from Political Disagreement is different, concerning only the initial identification of more knowledgeable voters. Whether such voters are all-things-considered more competent than their less informed peers is an empirical question about which this paper is silent.

4 Brennan, Against Democracy, 212.

5 Caplan, The Myth of the Rational Voter, 85; Brennan, Against Democracy, 192.

6 For overviews of the relevant empirical literature on voter ignorance, see Oppenheimer and 
ally, they might push self-interested politicians who are looking to pander to the electorate's preferences in the direction of such policies. If one wants to improve the overall quality of governance, those voters who know such facts ought to have comparatively more political power-or so epistocrats claim.

However, one might think that it is controversial whether the above really are facts. One might even think that for any putative social-scientific fact, there will be associated controversy. ${ }^{7}$ If such controversy abounds for any given putative social-scientific fact, the prospects for epistocrats seeking to delineate some uncontroversial body of political facts against which to measure the knowledge of voters seem dim. A crucial assumption underlying the case for epistocracy fails if there is no way to reliably identify voters who, in virtue of their greater levels of political knowledge, ought to be allocated comparatively more political power.

In support of the claim that the social sciences are mired in controversy, Reiss appeals to widespread expert disagreement among social scientists of various kinds. ${ }^{8}$ Consider the purported benefits of free trade. Such benefits are, at least in broad outline, agreed on by very many economists. ${ }^{9}$ But this agreement is not universal. Many economists, some lying outside of the mainstream, dissent. As Reiss puts it when discussing mainstream economic agreement on free trade and price controls: "The problem is that such agreement exists, if at all, at best among mainstream economists. When we look a little farther afield, for instance to heterodox economists, historians of economics, socio-economists and the like we are very unlikely to encounter agreement." ${ }^{10}$ Experts disagree about the benefits of free trade. It seems plausible, then, to grant that there is controversy on this issue. Of course, such controversy likely exists regarding virtually every other social-scientific issue of political importance. Social scientists often disagree with each other in a variety of domains, about the social problems that impact the most people, the underlying causes of various social problems, the appropriate policies to tackle such problems, the costliness of competing policies, and more. ${ }^{11}$

Additional support comes from reflection on two important sources of expert disagreement. First, although controversy often arises because of disagreement about the relevant nonmoral facts, much disagreement in the social sci-

Edwards, Democracy Despite Itself, 9-38; Somin, Democracy and Political Ignorance, 17-37; Brennan, Against Democracy, 23-53; and Achen and Bartels, Democracy for Realists, 36-41.

7 Reiss, "Expertise, Agreement, and the Nature of Social Scientific Facts," 186-91.

8 Reiss, "Expertise, Agreement, and the Nature of Social Scientific Facts," 187.

9 Caplan, The Myth of the Rational Voter, 50-93.

10 Reiss, "Expertise, Agreement, and the Nature of Social Scientific Facts," 186.

Friedman, Power without Knowledge, 46-47. 
ences has its roots in substantive moral disagreement. Claims about the benefits of free trade, about the economic harms wrought by restrictive immigration control, and about a wide array of other issues inevitably overlap with deeply controversial moral questions. Questions about the allocation of benefits and burdens from different economic policies are straightforwardly moral, as are questions about the appropriate way to aggregate different kinds of benefits or burdens. Questions about how we ought to make trade-offs between different values such as economic efficiency, equality, and freedom (among others) are paradigmatically moral questions, as are questions about the assignment of rights and responsibilities. Each of these questions is subject to vigorous dispute among professional social scientists and political theorists. To the extent that issues in the social sciences intersect with these questions, we should expect a certain degree of controversy in settling them.

Second, empirical generalizations in the social sciences are true (if they are true at all) only once certain contextual parameters are held fixed..$^{12}$ Empirical generalizations that are true in certain locations over certain timescales may not be true in other locations or over other timescales. With the introduction of such parameters, new loci of disagreement are thereby introduced, for the very choice of contextual parameter may be disputed. Naturally, there will also be straightforward nonmoral disagreement about the truth of certain empirical generalizations under transformations of the relevant parameters. ${ }^{13}$

Together, these sources of disagreement greatly limit the number of uncontroversial social-scientific facts against which a prospective epistocrat can measure the knowledge of voters. This, in turn, greatly decreases the feasibility of identifying some subset of voters who, because they possess the appropriate knowledge in greater proportions, ought to be allocated comparatively more political power. If this argument succeeds, a core assumption underlying the case for epistocracy is false.

To make the following discussion more precise, we can express the argument as follows:

1. There are no uncontroversial social-scientific facts.

2. If there are no uncontroversial social-scientific facts, then it is not possible to identify a subset of voters who possess more politically relevant knowledge than others.

Reiss, "Expertise, Agreement, and the Nature of Social Scientific Facts," 188-89.

13

Such disagreement will sometimes be nonmoral disagreement, but other times it will be about the sort of moral issues mentioned earlier. The worry about empirical generalizations, then, can be seen as a special form of our earlier two worries. Still, Reiss treats it separately, and I follow his lead here. 
3. If it is not possible to identify a subset of voters who possess more politically relevant knowledge than others, then epistocracy is not feasible.

4. Therefore, epistocracy is not feasible.

\section{BASIC POLITICAL FACTS}

The centrality accorded to knowledge of social-scientific facts in the Argument from Political Disagreement is understandable. Indeed, epistocrats themselves stress the importance of social-scientific knowledge. Still, this emphasis is something of a red herring. Not all politically relevant facts are social-scientific facts, and epistocratic proposals recognize this distinction. For instance, while discussing potential qualification exams for voters, Jason Brennan writes that "to keep the test objective and nonideological, we could limit it to basic facts and fundamental, largely uncontested social-scientific claims." ${ }^{14}$ Clearly, then, epistocrats do not think that all politically relevant facts are social scientific. Among such facts, they also include basic political facts. The upshot of this is clear: since there are some politically relevant facts that are not social scientific, the Argument from Political Disagreement fails. ${ }^{15}$

What are these basic political facts? Generally speaking, there are seemingly uncontroversial facts about the structure and function of important political institutions, the policy proposals of different candidates for office, existing policy and legislation (at the local, state, federal, and constitutional levels), the past actions of political figures, current budgetary spending, and more. Call facts like these basic political facts. The Argument from Political Disagreement fails if such facts are politically relevant. Specifically, premise 2 is false. One could simply grant the claim that there are no uncontroversial social-scientific facts while denying the further claim that such controversy precludes the identification of some subset of voters who possess more politically relevant knowledge than others. Epistocrats could endorse the allocation of more political power to voters who know more of the basic political facts since, as the empirical literature on voter ignorance shows, many voters are indeed ignorant of the basic political facts. ${ }^{16}$

Brennan, Against Democracy, 212, emphasis added.

Of course, one could also question the claim that the social sciences are as controversial as Reiss maintains. If, as Brennan claims, there are fundamental and largely uncontested social-scientific facts, the Argument from Political Disagreement fails in yet another way. However, I set this issue aside in this paper. The Argument from Political Disagreement fails even if the social sciences are controversial through and through.

Somin, Democracy and Political Ignorance, 17-37; Brennan, Against Democracy, 23-53. 
There are several ways in which a proponent of the Argument from Political Disagreement might push back on this appeal to the basic political facts. First, one might reject the claim that such basic political facts are politically relevant. Some such facts look more like political trivia than vitally important political information. For instance, knowing the identity of the twenty-fourth president of the United States is unimportant, even though it is a basic historical political fact. One might even question the significance of facts about things like the identity of one's political representatives, the details of national budgets, and so on. ${ }^{17}$ Knowledge of these independent facts does not obviously play a role in the decision-making processes of voters. If that is right, then Reiss's argument might succeed after all.

But the claim that all such basic political facts are unimportant trivia is deeply implausible. When voters do not know who has enacted certain policies, they can assign praise (or blame) inaccurately; when they do not know how much of the federal budget is apportioned to different areas, they can be misled into believing that spending should be cut (or increased) in these areas; when they do not know the policy proposals of candidates, they might vote in ways they would not otherwise; and so on. ${ }^{18}$ This last point is important: when voters are ignorant of the basic political facts, they can vote in ways that they would not have wanted to if they had known otherwise. ${ }^{19}$ Voters often go wrong by their own lights when they have false beliefs about the basic political facts. Whenever they do go wrong, they can end up with policies (and leaders) they do not want. The basic political facts are not only politically relevant but also often central to voter decision-making.

Rather than denying the political relevance of the basic political facts, a proponent of the Argument from Political Disagreement might instead reject the claim that they are uncontroversial. After all, many voters do not know them, and many voters disagree about them. Instead of the earlier Argument from Political Disagreement, we could have an amended version focusing on the basic political facts:

1. There are no uncontroversial basic political facts.

2. If there are no uncontroversial basic political facts, then it is not possible to identify a subset of voters who possess more politically relevant knowledge than others. 
3. If it is not possible to identify a subset of voters who possess more politically relevant knowledge than others, then epistocracy is not feasible.

4. Therefore, epistocracy is not feasible.

But the basic political facts are controversial only in a highly attenuated sense. First, it is important to note that the basic political facts bear none of the indicators of controversy outlined in the previous section regarding controversy in the social sciences. There is no expert disagreement about the basic political facts, there are no underlying substantive moral disputes lurking beneath the basic political facts, the truth of basic political facts is not hostage to contextual parameters about which there may be disagreement, and so on. Additionally, the basic political facts, unlike controversial putative facts in the social sciences, are easily confirmed. Given the hallmarks of controversy enumerated earlier in the paper, things like the purported benefits of free trade are understandably hard to confirm or disconfirm. But it is not hard to confirm, say, who your senators are, what their policies are (at least in broad outline), and the like.

A proponent of the Argument from Political Disagreement might insist that the presence of disagreement is by itself necessary and sufficient for there to be controversy. Since there is disagreement about some of the basic political facts, there is therefore controversy about them. But if any disagreement whatsoever constitutes controversy, then virtually nothing is uncontroversial. On this account, it is controversial whether the earth is flat, whether Dublin is the capital of Ireland, and more. I simply assume that such verdicts are misguided, and that a conception of controversy this expansive cannot bear the weight placed on it in the Argument from Political Disagreement. Presumably, proponents of this argument have something more demanding in mind. But more demanding conceptions of controversy, while much more plausible, will not count the basic political facts as controversial. For instance, if controversy requires expert disagreement, then the basic political facts are not controversial. If it requires epistemic peer disagreement, then the basic political facts are not controversial since the relevant disputes do not always involve epistemic peers. ${ }^{20}$ It is plausible, then, to conclude that the basic political facts are not controversial in the right way for the Argument from Political Disagreement to succeed. Since the basic political facts are both politically relevant and uncontroversial, the Argument from Political Disagreement fails.

20 For helpful discussion of competing accounts of what it is to be an epistemic peer, see Gelfert, "Who Is an Epistemic Peer?" 


\section{MINIMAL EPISTOCRACY}

If we set aside all putative social-scientific facts on the grounds that they are controversial, what sort of epistocracy are we left with? More demanding epistocratic proposals seeking to empower groups of political experts in virtue of their specialized social-scientific knowledge are ruled out. But a minimal form of epistocracy focused on those voters who possess more knowledge of the basic political facts is still viable. A minimal epistocracy might implement voter qualification exams pivoting around the relevant facts, with failure to pass the exams resulting in disenfranchisement. Alternatively, it could amplify the political power of more knowledgeable voters by allocating more votes to them in proportion to their knowledge. A different method still could be to simulate voter political preferences, relative to their demographic group, under simulated conditions of full knowledge of some set of the basic political facts. ${ }^{21}$

Nevertheless, one might still have reservations about minimal epistocracy. For instance, one might claim that the basic political facts, while neither politically irrelevant nor controversial in any meaningful sense, are such that allocating more political power to voters who know them will not gain us much. Epistocratic reforms, after all, are supposed to mitigate the harmful effects of voter ignorance. But perhaps epistocratic reforms pivoting around a minimum core of basic political facts will not mitigate such effects enough. Perhaps they would even worsen outcomes relative to the status quo. ${ }^{22}$

However, this criticism is entirely distinct from the original argument with which we began. The Argument from Political Disagreement is not an argument to the effect that the overall costs of transitioning to epistocracy (and away from democracy) outweigh the benefits. Such concerns about the overall expected costs and benefits are perfectly general, applying to prospective epistocratic arrangements even if_-pace the Argument from Political Disagreement—it were trivially easy to identify some subset of voters who possess much more politically relevant knowledge than others. Instead, the Argument from Political Disagreement is an attempt to show that epistocrats cannot identify some subset of

21 Those familiar with the literature on epistocracy will recognize these options as, respectively, restricted suffrage, plural voting, and what Brennan calls "rule by simulated oracle" (Against Democracy, 204-30).

22 For instance, epistemic democrats claim that collections of individually ill-informed agents can, under the right conditions, epistemically outperform numerically smaller collections of more knowledgeable agents. See Landemore, Democratic Reason; Schwartzberg, "Epistemic Democracy and Its Challenges"; and Goodin and Spiekermann, An Epistemic Theory of Democracy. Naturally, it is controversial whether actual democracies satisfy the relevant conditions. For some critical discussion, see Brennan, Against Democracy, 172-203. 
voters who possess more knowledge of politically relevant facts. The existence of uncontroversial and politically relevant basic political facts shows that this is mistaken.

I conclude, then, that some voters do possess more politically relevant knowledge than others and that the Argument from Political Disagreement fails. At the very least, a minimal form of epistocracy is still feasible. If we are to reject epistocracy, we must do so on other grounds. ${ }^{23}$

\section{Rutgers University-New Brunswick adam.gibbons@rutgers.edu}

\section{REFERENCES}

Achen, Christopher H., and Larry M. Bartels, Democracy for Realists: Why Elections Do Not Produce Responsive Government. Princeton, NJ: Princeton University Press, 2016.

Bartels, Larry M. "Uninformed Votes: Information Effects in Presidential Elections." American Journal of Political Science 40, no. 1 (February 1996): 194-230.

Brennan, Jason. Against Democracy. Princeton, NJ: Princeton University Press, 2016.

Caplan, Bryan. The Myth of the Rational Voter: Why Democracies Choose Bad Policies. Princeton, NJ: Princeton University Press, 2007.

Estlund, David M. Democratic Authority: A Philosophical Framework. Princeton, NJ: Princeton University Press, 2008.

Friedman, Jeffrey. Power without Knowledge: A Critique of Technocracy. New York: Oxford University Press, 2019.

Fuller, Roslyn. In Defense of Democracy. Medford, MA: Polity Press, 2019.

Gaus, Gerald. "Is the Public Competent? Compared to Whom? About What?" Critical Review 20, no. 3 (2008): 291-311.

Gelfert, Axel. "Who Is an Epistemic Peer?" Logos and Episteme 2, no. 4 (2011): 507-14.

Goodin, Robert E., and Kai Spiekermann. An Epistemic Theory of Democracy. Oxford: Oxford University Press, 2018.

Hochschild, Jennifer L., and Katherine Levine Einstein. Do Facts Matter? Information and Misinformation in American Politics. Norman: University of Oklahoma Press, 2015.

23 Thanks to Alex Guerrero, Oliver Traldi, and three anonymous reviewers for their feedback on this paper. 
Landemore, Hélène. Democratic Reason: Politics, Collective Intelligence, and the Rule of the Many. Princeton, NJ: Princeton University Press, 2013.

Oppenheimer, Danny, and Mike Edwards. Democracy Despite Itself: Why a System That Shouldn't Work at All Works So Well. Cambridge, MA: MIT Press, 2012.

Reiss, Julian. "Expertise, Agreement, and the Nature of Social Scientific Facts or: Against Epistocracy." Social Epistemology 33, no. 2 (2019): 183-92.

Schwartzberg, Melissa. "Epistemic Democracy and Its Challenges." Annual Review of Political Science 18 (May 2015): 187-203.

Somin, Ilya. Democracy and Political Ignorance: Why Smaller Government Is Better. Stanford, CA: Stanford University Press, 2013. 